\title{
EVALUASI PENERAPAN SISTEM PENGENDALIAN INTERN PENERIMAAN KAS PADA BLU RSUP PROF.DR.R.D. KANDOU MANADO
}

\author{
Tirza Melia Sambeka \\ Harijanto Sabijono \\ Treesje Runtu \\ Fakultas Ekonomi dan Bisnis Jurusan Akuntansi \\ Universitas Sam Ratulangi \\ email: tirzamelia@yahoo.com
}

\begin{abstract}
ABSTRAK
Sistem pengendalian intern penerimaan kas harus dilaksanakan seefektif mungkin dalam suatu perusahaan untuk mencegah dan menghindari terjadinya kesalahan, kecurangan, dan penyelewengan. Tujuan dari penelitian ini adalah mengevaluasi pengendalian intern yang dilakukan, guna mendapatkan gambaran yang jelas mengenai pengendalian intern penerimaan kas yang diterapkan pada BLU RSUP Prof.Dr.R.D.Kandou Manado. Untuk memperoleh data yang diperlukan maka penulis menggunakan pengumpul data berupa observasi, wawancara dan dokumentasi. Berdasarkan hasil penelitian, sistem pengendalian penerimaan kas pada BLU RSUP Prof.dr.R.D. Kandou Manado sudah memadai. Selain itu telah ditemukan beberapa kelemahan yang harus menjadi perhatian manajemen, terutama pada dokumentasi dan penyampaian informasi. Penulis menyarankan agar pengendalian yang telah berjalan hingga saat ini dapat dipertahankan dan disesuaikan dengan kondisi perusahaan.
\end{abstract}

Kata kunci : Evaluasi, sistem pengendalian intern, penerimaan kas.

\begin{abstract}
Internal control system of cash receipts should be implemented as effectively as possible in a company to prevent and avoid the occurrence of errors, fraud and abuse. The purpose of this research was to evaluate the internal control conducted, to get a clear view of the internal control of cash receipts are applied to the BLU RSUP. Prof.Dr.R.D.Kandou Manado. To obtain the necessary data, the researcher used data collectors in the form of observations, interviews and documentation. Based on the results o the research, system controlling of cash receipts in the department is sufficient. But other than that, the researcher found several weakness that should be a concern of management, especially on the Entity's documentation and the delivery of information. The writer suggested that the control has been run to date can be maintained and adapted o the conditions of the company.
\end{abstract}

Keywords: evaluation, internal control system, cash receipt. 


\section{PENDAHULUAN}

\section{Latar Belakang Penelitian}

Struktur organisasi yang baik sangatlah diperlukan dalam perusahaan sebagai satu kesatuan ekonomi yang berdiri sendiri. Informasi berupa laporan-laporan serta analisisanalisis diperlukan manajemen agar kegiatan usaha dapat berjalan secara efektif dan efisien. Dengan sistem akuntansi yang baik, diharapkan manajer akan mampu mengendalikan perusahaan, agar kegiatan usahanya berkembang. Oleh karenanya, pemimpin suatu perusahaan sangat membutuhkan suatu sistem dalam menjalankan pengendalian intern agar dapat mengamankan atau mengawasi aset perusahaan.

Menurut Donald E. Kieso, dkk (2008), "Kas adalah aktiva lancar yang paling likuid, yang berarti dapat digunakan secara langsung untuk keperluan operasional perusahaan. Kas terdiri dari uang tunai dan saldo perusahaan di bank. Uang tunai terdiri dari uang kertas dan uang logam". Setara kas adalah investasi yang sifatnya likuid, berjangka pendek dan yang dengan cepat dapat dijadikan kas dalam jumlah tertentu tanpa menghadapi risiko perubahan nilai yang signifikan.

Rumah Sakit sebagai salah satu institusi pelayanan kesehatan memiliki berbagai macam fungsi, antara lain fungsi pelayanan, pendidikan dan penelitian, yang mencakup berbagai tingkatan dan jenis kegiatan. Di sisi lain rumah sakit bersifat padat modal (memerlukan biaya besar), padat karya (memerlukan sumber daya manusia dalam jumlah cukup banyak dimana sebagian besar tidak dapat digantikan dengan alat), serta padat teknologi (memerlukan berbagai alat dengan teknologi mutakhir).

Objek penelitian pada penulisan skripsi ini adalah Badan Layanan Umum (BLU) Rumah Sakit Umum Pusat Prof. Dr. R.D. Kandou Manado sebagai institusi di bidang pelayanan kesehatan. Pasien yang berobat tidak sedikit dan jangkauan wilayah rumah sakit cukup luas dan juga merupakan rumah sakit rujukan bagi Rumah Sakit Daerah, Puskesmas di wilayah Manado serta rumah sakit pemerintah lain di sekitar Sulawesi Utara. Adapun aktivitas transaksi perusahaan meliputi penerimaan dan pengeluaran kas. Penerimaan kas perlu adanya pengawasan dan pengendalian intern meskipun sudah ada pemisahan fungsi. Melihat arti penting pengendalian intern bagi manajemen Rumah Sakit dalam pengeloaan dana khususnya penerimaan kas, penulis tertarik untuk mengevaluasi sistem penerimaan kas perusahaan apakah sudah dilaksanakan secara memadai atau tidak. Dengan demikian penulis mengambil judul penulisan skripsi ini yaitu: "Evaluasi Penerapan Sistem Pengendalian Intern Penerimaan Kas Pada BLU RSUP Prof. Dr. R.D. Kandou Manado".

\section{Perumusan Masalah}

Berdasarkan latar belakang yang diuraikan di atas maka dapat dibuat perumusan masalah yaitu apakah sistem pengendalian intern penerimaan kas di BLU RSUP Prof. DR. R.D. Kandou Manado dilakukan secara memadai atau tidak.

\section{Tujuan Penelitian}

Penelitian ini dilakukan dengan tujuan untuk mengevaluasi sistem pengendalian intern penerimaan kas di BLU RSUP Prof. DR. R.D. Kandou Manado apakah sudah

\section{Manfaat Penelitian} dilaksanakan dengan memadai atau tidak.

\section{a) Manfaat Teotitis}

Memberi manfaat bagi pengembangan ilmu pengetahuan khususnya di bidang akuntansi manajemen, dan dapat menjadi referensi bagi peneliti lain untuk mengadakan penelitian selanjutnya guna melakukan evaluasi yang lebih baik, tentang pengendalian intern atas penerimaan kas dalam mengefektifkan penggunaan dana perusahaan.

b) Manfaat Praktis

1. Bagi Perusahaan

Hasil simpulan dari penelitian ini diharapkan pengelolaan penerimaan kas di perusahaan dapat disempurnakan penggunaan standar dan praktek Akuntansinya dan dapat dijadikan bahan pertimbangan dan masukan bagi manajemen perusahaan 
mengenai perbaikan dari kelemahan-kelemahan pengendalian intern penerimaan kas yang diterapkan perusahaan saat ini sehingga dapat meminimalkan kecurangan atau penyelewengan dana.

2. Bagi Akademisi

Sebagai bahan masukan dan bahan referensi sehingga dapat menerapkan perpaduan yang tepat antara praktik dan keadaan teoritis yang diperoleh dari bangku kuliah khususnya bidang sistem pengendalian intern penerimaan kas.

3. Bagi Penulis

Dengan membandingkan teori-teori pengendalian intern atas penerimaan kas dengan aplikasinya terhadap pengendalian intern penerimaan kas, penulis dapat lebih memahami dan mencermati manfaat pengendalian intern terhadap penerimaan kas.

\section{Konsep Akuntansi}

\section{TINJAUAN PUSTAKA}

Akuntansi mempunyai peranan yang sangat penting dalam suatu perusahaan, kemajuan perusahaan dapat dilihat dari proses akuntansi perusahaan tersebut. Berikut definisi dari akuntansi menurut pendapat beberapa ahli.

Menurut Lili M. Sadeli (2006:2) : "Akuntansi adalah proses mengidentifikasikan, mengukur dan melaporkan informasi untuk membuat pertimbangan dan mengambil keputusan yang tepat bagi pemakai informasi tersebut".

Menurut Rudianto (2009:4) : "Akuntansi sebagai sebuah sistem yang menghasilkan informasi keuangan kepada pihak-pihak yang berkepentingan mengenai aktivitas ekonomi dan kondisi perusahaan".

Dari beberapa definisi yang sudah dikemukakan para ahli tersebut maka penulis mengambil kesimpulan bahwa definisi akuntansi adalah semua kegiatan seperti pencatatan, penggolongan, pengidentifikasian, mengukur dan melaporkan informasi ekonomi dalam sebuah sistem yang menghasilkan informasi keuangan kepada pihak-pihak yang berkepentingan untuk mengambil tindakan-tindakan mengenai aktifitas ekonomi dan kondisi perusahaan.

\section{Konsep Akuntansi Manajemen}

Dalam dunia usaha, mulai dari usaha kecil sampai pada perusahaan besar membutuhkan informasi akuntansi sebagai alat pengawasan maupun sebagai dasar pengambilan keputusan.

Menurut Horison, Horngren, (2004 : 5), akuntansi manajemen didefinisikan : "Management Accounting is the process o identifying, measuring, accumulating, analizing, preparing, interpreting, and communicating information that helps managers fulfill organizational objectives". Dari definisi ini dapat diketahui bahwa akuntansi manajemen mencakup ruang lingkup yang amat luas yaitu mencakup analisis keuangan, internal kontrol, sistem akuntansi, akuntansi biaya, audit internal, dan akuntansi keuangan.

Menurut Abdul Halim dan Bambang Supomo (2001 : 3), "Akuntansi manajemen adalah suatu kegiatan (proses) yang menghasilkan informasi keuangan bagi manajemen untuk pengambilan keputusan ekonomi dalam melaksanakan fungsi manajemen".

\section{Sistem Informasi Akuntansi Manajemen}

Informasi akuntansi manajemen dikelola dalam suatu sistem, yaitu sistem informasi akuntansi manajemen.

Menurut Krismiadji, (2005) : "Sistem informasi akuntansi manajemen merupakan sisem informasi yang menghasilkan output dengan menggunakan input dan memprosesnya untuk mencapai tujuan khusus manajemen. Tidak ada suatu criteria formal yang menjelaskan

\section{Pengendalian Intern} sifat dari input atau proses, bahkan output dari sistem informasi akuntansi manajemen" 
Menurut Werren Reeve, dkk (2005) terdapat beberapa konsep dasar pengendalian intern berikut ini:

1. Pengendalian intern merupakan suatu proses untuk mencapai tujuan tertentu. Pengendalian intern itu sendiri bukan merupakan suatu tujuan. Pengendalian intern merupakan suatu rangkaian tindakan yang bersifat pervasif dan menjadi bagian tidak terpisahkan.

2. Pengendalian intern dijalankan oleh orang. Pengendalian intern bukan hanya terdiri dari pedoman kebijakan dan formulir, namun dijalankan oleh orang dari setiap jenjang organisasi, yang mencakup dewan komisaris, manajemen dan personel lain.

3. Pengendalian intern dapat diharapkan mampu memberikan keyakinan memadai, bukan keyakinan mutlak, bagi manajemen dan dewan komisaris entitas. Keterbatasan yang melekat dalam semua sistem pengendalian intern dan pertimbangan manfaat dan pengorbanan dalam pencapaian tujuan pengendalian menyebabkan pengendalian intern tidak dapat memberikan keyakinan mutlak.

\section{Tujuan Pengendalian Intern}

Menurut Mulyadi (2008 : 181), " tujuan pengendalian intern adalah sebagai berikut :

1) Keandalan informasi keuangan,

2) Kepatuhan terhadap hukum dan peraturan yang berlaku,

3) Efektifitas dan efisiensi operasi".

\section{Sistem Pengendalian Intern}

Menurut Horison Horngren, (2004), istilah sistem pengendalian intern mempunyai dua pengertian dalam arti sempit dan dalam arti luas. Dalam arti sempit istilah tersebut merupakan prosedur-prosedur dan mekanis untuk memeriksa ketelitian dari data-data administrasi seperti pencocokan penjumlahan mendatar dan penjumlahan kebawah. Dalam arti luas sistem pengendalian intern merupakan sistem yang terdiri dari berbagai unsur dengan tujuan untuk melindungi harta milik, meneliti ketepatan dan sampai seberapa jauh data akuntansi dapat dipercaya mendorong efisiensi dan menjamin dipatuhinya kebijakan perusahaan.

Sedangkan menurut Mulyadi (2008:163) "mendefenisikan sistem pengendalian intern meliputi struktur organisasi, metode, ukuran-ukuran yang dikoordinasikan untuk menjaga kekayaan organisasi, mengecek ketelitian dan keandalan data akuntansi, mendorong efisiensi dan mendorong dipatuhinya kebijakan manajemen".

Jadi dapat disimpulkan bahwa sistem pengendalian intern merupakan suatu proses yang dilakukan untuk mencapai tujuan organisasi yang terdiri dari berbagai kebijakan, prosedur, teknik, peralatan fisik, dokumentasi, dan manusia.

Kas

Menurut Donald E. Kieso,dkk (2008) : "Kas adalah aktiva lancar yang paling likuid, yang berarti dapat digunakan secara langsung untuk keperluan operasional perusahaan".

Menurut Ikatan Akuntan Indonesia (2010: 02) "Kas adalah alat pembayaran yang siap dan bebas dipergunakan untuk membiayai kegiatan umum perusahaan". Kas adalah uang tunai yang paling likuid sehingga pos ini biasanya ditempatkan pada urutan teratas dari aset. Yang termasuk dalam kas adalah seluruh alat pembayaran yang dapat digunakan dengan segera seperti uang kertas, uang logam dan saldo rekening giro di bank kas terdiri dari saldo kas (cash on hand) dan rekening giro. Arus masuk dan arus keluar kas atau setara kas disebut arus kas. Cash on hand adalah saldo kas yang ada ditangan perusahaan (biasa disebut dengan Kas saja), sedang rekening giro adalah kas yang ada di Bank (disebut dengan Kas Bank atau Bank saja).

\section{Pengertian Penerimaan Kas}

Mengacu kepada pendapat Mulyadi (2004: 455), pengertian penerimaan kas adalah kas yang diterima perusahaan, baik yang berupa uang tunai maupun surat-surat berharga yang 
mempunyai sifat dapat segera digunakan, yang berasal dari transaksi perusahaan, maupun penjualan tunai, pelunasan piutang atau transaksi lainnya yang dapat menambah kas perusahaan: "Sumber penerimaan kas terbesar suatu perusahaan dagang berasal dari transaksi penjualan tunai."

\section{Prosedur Penerimaan Kas}

Bagian-bagian yang terkait aktiva lancar dari penjualan tunai:

1. Bagian Order Penjualan : bertugas membuat faktur penjualan 3 lembar (untuk pembeli, bagian gudang, arsip bagian penjualan).

2. Bagian Kasa : bertugas menerima pembayaran, memasukkan data ke register kas, memberi cap lunas, faktur bersama pita register diserahkan ke bagian pengiriman selanjutnya membuat bukti setoran ke bank.

3. Bagian Pengiriman : bertugas menerima barang dan faktur ke 2 dari gudang lalu mencocokkan dengan faktur yang di cap lunas dan pita register diserahkan ke bagian jurnal dan laporan.

4. Bagian Jurnal dan Laporan : bertugas menerima faktur lembar ke 1 dan pita register lalu mencatat ke buku jurnal penerimaan kas.

\section{Bagian-Bagian yang Terkait dalam Prosedur Penerimaan Kas}

Bagian-bagian yang terkait dalam prosedur penerimaan kas adalah :

1. Bagian Sekretariat

Bagian ini bertanggung jawab dalam pencatatan penerimaan cek dan surat pemberitahuan melalui pos dari para debitur perusahaan. Fungsi sekretariat bertugas membuat daftar surat pemberitahuan atas dasar surat pemberitahuan yang diterima bersama cek dari debitur.

2. Bagian Penagihan

Bagian ini bertanggung jawab untuk melakukan penagihan kepada debitur perusahaan berdasarkan daftar piutang pada fungsi akuntansi.

3. Bagian Kas

Bagian ini bertanggung jawab atas penerimaan cek dari bagian sekretariat dan menyetorkannya ke bank dalam jumlah penuh.

4. Bagian Akuntansi

Bagian ini bertanggung jawab dalam pencatatan penerimaan kas dari piutang ke jurnal penerimaan kas dan berkurangnya piutang dalam kartu piutang.

5. Bagian Pemeriksaan Intern

Bagian ini bertanggung jawab dalam melaksanakan perhitungan kas pada bagian kas secara periodik dan melakukan rekonsiliasi bank untuk mengecek ketelitian catatan kas yang diselenggarakan oleh bagian akuntansi.

\section{Prinsip-prinsip Pengendalian Intern atas Penerimaan Kas}

Prinsip-prnsip pengendalian intern penerimaan kas adalah sebagai berikut :

a. Menetapkan tanggung jawab pengelolaan dan pengawasan secara fisik.

b. Semua surat masuk harus dibuka dengan pengawasan yang cukup.

c. Harus segera dibuat catatan oleh yang membuat surat tentang cek atau uang yang diterima dari siapa saja, jumlahnya dan digunakan untuk apa.

d. Semua penjualan tunai harus dibuatkan nota penjualan yang sudah diberi nomor urut atau dicabut dalam mesin cash register.

e. Daftar penerimaan uang harus dicocokkan dengan jurnal penerimaan uang.

f. Tembusan nota penjualan tunai harus dikirimkan ke kasir dan bagian pengiriman.

g. Bukti setor ke bank setiap hari dicocokkan dengan daftar penerimaan uang harian dan catatan dalam jurnal penerimaan uang.

h. Semua penerimaan uang harus disetorkan pada hari itu juga atau pada awal hari kerja berikutnya. 
Jenis Penelitian

\section{METODE PENELITIAN}

Jenis penelitian yang dilakukan adalah penelitian dengan pendekatan spesifik untuk menekiti masalah-masalah secara lebih mendalam dengan tujuan mengungkapkan fakta dalam hubungan sebab akibat, mencari keterangan-keterangan sebab terjadinya masalah dan bagaimana memecahkannya. Penelitian ini bertujuan untuk mengevaluasi penerapan sistem pengendalian terhadap penerimaan kas apakah sudah memadai.

\section{Tempat dan Waktu Penelitian}

Penelitian bertempat di BLU RSUP Prof.Dr.R.D.Kandou Manado yang terletak di Jalan Raya Tanawangko. Adapun kegiatan penelitian dilaksanakan pada bulan Januari 2013 sampai selesai.

\section{Prosedur Penelitian}

Melakukan observasi pada perusahaan dan wawancara terhadap pegawai perusahaan. Mengumpulkan dokumen-dokumen dan data yang didapat serta mempelajarinya untuk memahami akan kondisi-kondisi yang ada dalam perusahaan, kemudian mengevaluasi perbedaan-perbedaan yang terjadi dan menentukan apakah perbedaan itu menyangkut hal-hal yang mendasar, dari evaluasi ini dapat diketahui apakah sistem pengendalian penerimaan kas sudah memadai.

\section{Populasi dan Sampel \\ Populasi}

Populasi (population) mengacu pada keseluruhan kelompok orang, kejadian, atau hal minat yang ingin peneliti investigasi.Obyek penelitian pada BLU RSUP Prof.Dr. R.D. Kandou yang berkedudukan di Jalan Raya Tanawangko. Populasi yang digunakan penelitian ini adalah faktur penerimaan kas di perusahaan tersebut.

\section{Sampel}

Sampel (sample) adalah sebagian dari populasi. Sampel terdiri atas sejumlah anggota yang dipilih dari populasi. Sampel adalah subkelompok atau sebagian dari populasi (Uma Sekaran, 2006).

\section{Teknik Pengambilan Sampling}

Teknik pengambilan adalah merupakan teknik pengambilan sampel untuk menentukan sampel yang akan digunakan dalam penelitian terdapat berbagai teknik sampling yang digunakan. Teknik sampling yang akan digunakan dalam penelitian adalah attribute sampling atau disebut pula proportional sampling yang digunakan terutama untuk menguji efektivitas pengendalian intern (dalam pengujian pengendalian).

\section{Metode Pengumpulan Data}

Jenis data dalam penelitian ini adalah data subjek (self report data), dan data documenter (documentary data), yaitu:

1. Data Subyek (self report data)

Data penelitian yang berupa opini, sikap, pengalaman, atau karakteristik dari seseorang atau sekelompok orang yang menjadi subjek penelitian (responden).

2. Data Dokumenter (documentary data)

Data dokumenter adalah jenis data penelitian yang antara lain berupa: faktur, jurnal, surat-surat, notulen hasil rapat, memo atau alamat dalam bentuk laporan program. Data dokumenter memuat apa dan kapan suatu kejadian atau transaksi, serta siapa yang terlibat dalam suatu kejadian. Data dokumenter dalam penelitian ini adalah formulirformulir yang terkait dengan aktivitas penerimaan kas pada BLU RSUP Prof.Dr. R.D. Kandou, slip pembayaran administrasi Rumah Sakit dari pasien, slip pembayaran

\section{Sumber Data} konsultasi dokter spesialis, biaya tindakan dan dokumen pendukung lainnya.

Sumber data dalam penelitian ini meliputi : 
1. Data Primer mengacu pada informasi yang diperoleh dari tangan pertama oleh peneliti yang berkaitan dengan variabel minat untuk tujuan spesifik studi. Dalam hal ini responden harus menjawab beberapa pertanyaan yang terdapat dalam kuesioner yang diberikan oleh peneliti.

2. Data Sekunder mengacu pada informasi yang dikumpulkan dari sumber yang telah ada. Data sekunder dalam penelitian ini adalah berupa data dokumen perusahaan, seperti dokumen keuangan, buku standar operasional perusahaan, dokumen-dokumen yang terkait dengan penerimaan kas.

\section{Teknik Pengumpulan Data}

Penulis melakukan penelitian ini untuk mendapatkan data mengenai objek yang akan diteliti dengan menggunakan beberapa pendekatan teknik yang diperlukan, diantaranya adalah Studi Lapangan (Field Research). Metode yang digunakan adalah metode wawancara, observasi, dan survei dokumen.

\section{Wawancara}

Penulis melakukan wawancara kepada staf BLU RSUP Prof. Dr. R.D Kandou Manado untuk mendapatkan informasi tentang sistem pengendalian intern yang berlaku pada perusahaan.

\section{Observasi}

Observasi dilakukan untuk mengumpulkan data secara detail. Observasi dilakukan dengan mengamati secara langsung proses penerimaan kas dari konsumen dalam hal ini pasien.

\section{Survei Dokumen}

Survei dokumen ini dilakukan dengan cara melihat dokumen-dokumen yang terkait serta bukti-bukti penerimaan kas, dan membaca buku yang berhubungan dengan sistem penerimaan kas.

\section{Metode Analisis Data \\ Metode Kualitatif}

Metode analisis data pada penelitian ini dengan menggunakan unsur sistem pengendalian intern, yaitu:

1. Struktur organisasi.

2. Otorisasi dan prosedur pencatatan.

3. Praktik yang sehat.

4. Karyawan yang mutunya sesuai dengan tanggungjawabnya.

\section{Metode Kuantitatif}

Pengujian dilakukan pada kelengkapan dokumen-dokumen seperti slip pembayaran dan bukti-bukti transaksi lainnya, otorisasi yang terdapat dalam dokumen dan nomor urut yang tercetak pada dokumen tersebut.

\section{Teknik Analisis Data}

Berdasarkan masalah yang ada, langkah-langkah dalam analisis data pada penelitan ini adalah sebagai berikut :

1. Menganalisis data

2. Merumuskan masalah

3. Teknik pengumpulan data

4. Melakukan analisis terhadap bahan penelitan yang ada

5. Memberikan kesimpulan

6. Memberikan saran

\section{Gambaran Umum Objek Penelitian}

\section{HASIL PENELITIAN DAN PEMBAHASAN}


Badan Layanan Umum (BLU) RSUP Prof. Dr. R.D. Kandou Manado berawal dari RSU Gunung Wenang Manado yang terletak di Kelurahan Wenang Kota Manado.Didirikan pada zaman Hindia Belanda dengan nama KONINGEN WILHELMINA ZIEKENHEUIS (K.W.Z). Tahun 1942, tentara Koigun Jepang menduduki Kota Manado dan KWZ diganti namanya menjadi KOIGUN BYOIN. Pada tahun 1945, sesudah Perang Dunia KOIGUN BYOIN mengalami kerusakan berat dan direhabilitasi.

Berdasarkan Keputusan Menteri Kesehatan RI nomor 730/Menkes/SK/VI/2004 tahun 2004 telah ditetapkan nama Rumah Sakit Umum Pusat Manado menjadi Rumah Sakit Umum Prof.Dr.R.D.Kandou Manado. Selanjutnya pada 26 Juni 2007, RSUP Prof. Dr.R.D. Kandou Manado ditetapkan sebagai instansi yang menerapkan PPK-BLU berdasarkan Keputusan Menteri Kesehatan No. 756/MENKES/SK/VI/2007 dan Keputusan Menteri Keuangan No.272/Keu.05.2007 tanggal 21 Juni 2007.

\section{Visi dan Misi Perusahaan}

Visi

Misi

"Menjadi Rumah Sakit Pendidikan Unggulan di Kawasan Timur Indonesia Bagian Utara"

1. Melaksanakan pelayanan medis,keperawatan,penunjang yang professional, bermutu, tepat waktu dan terjangkau oleh seluruh lapisan masyarakat;

2. Melaksanakan pendidikan,pelatihan dan penelitian untuk pengembangan SDM

3. Melaksanakan pengelolaan administrasi umum,keuangan dan anggaran yang efektif, efesien serta akuntabel

4. Meningkatkan sarana dan prasarana Rumah Sakit dalam memberikan pelayanan

\section{Struktur Organisasi}

Struktur organisasi merupakan salah satu alat bagi manajemen atau pimpinan perusahaan untuk mengendalikan kegiatannya. Proses pembentukannya dimulai dengan menetapkan kegiatan-kegiatan yang harus dilaksanakan untuk mencapai tujuan perusahaan yang telah ditetapkan.Setiap kegiatan akan dibagi ke dalam unit-unit kegiatan yang lebih kecil, dengan disertai perincian tugas dari masing-masing karyawan yang menjalankan tugasnya. Selanjutnya tugas tersebut dibagi-bagi dan ditentukan bagian-bagian mana yang akan mengerjakan suatu tugas atau kelompok tugas tertentu. Apabila diperlukan di dalam suatu bagian masih bisa dibentuk sub bagian yang lebih kecil sesuai dengan bentuk bagian yang diperlukan dalam organisasi.Tahap terakhir adalah menentukan hubungan antara tugas yang satu dengan tugas yang lain. Penentuan ini agar tercipta kerjasama yang baik dan terarah diantara bagian-bagian tersebut, untuk mencapai tujuan yang telah ditetapkan.

\section{Hasil Penelitian}

\section{Sistem Pengendalian Intern Penerimaan Kas Pada BLU RSUP Prof.Dr.R.D.Kandou Manado}

Sistem pengendalian intern merupakan istilah yang telah umum dan banyak digunakan sebagai kepentingan. Istilah pengendalian intern diambil dari terjemahan istilah "Internal Control". Untuk mengetahui sistem pengendalian yang ada pada perusahaan, maka terlebih dahulu kita harus mengetahui mengenai pengendalian intern yang terdapat dalam suatu perusahaan. Hal ini bertujuan agar tidak terjadi penyimpangan atas kas sebagai aset perusahaan.

Adapun sistem pengendalian intern pada BLU RSUP Prof.Dr.R.D.Kandou Manado adalah :

1. adanya sistem atau prosedur dan dokumentasi yang dapat diperiksa dari laporan keuangan sampai ke dokumen asal. 
2. adanya dokumentasi sehingga memungkinkan untuk diperiksa kembali oleh pihak lain, baik dari internal perusahaan maupun pemeriksaan dari luar perusahaan (external auditor).

3. adanya pemisahan tugas, yaitu adanya pemisahan tanggung jawab, pemisahan pelaksanaan kegiatan. Sebagai contoh : untuk melaksanakan pencatatan penerimaan dan pengeluaran kas adalah seorang staf akuntansi; yang melakukan pembayaran adalah staf kas kecil; yang menyimpan uang kas adalah kepala kasir.

\section{Prosedur Penerimaan Kas}

Bagian-bagian yang terkait aktiva lancar dari penjualan tunai:

1. Bagian Kasir

Bertugas menerima bukti registrasi dan pembayaran tunai dari pasien umum, memasukkan data ke register kas, memberi cap lunas dengan kwitansi selanjutnya membuat bukti setoran ke bank.

2. Bagian Mobilisasi Dana

Bertugas menerima bukti setoran ke bank yang di cap lunas dan bukti registrasi serta kwitansi diserahkan ke bagian jurnal dan laporan.

3. Bagian Jurnal Dan Laporan

Bertugas menerima bukti setoran ke bank yang di cap lunas dan kwitansi lalu mencatat bukti penerimaan kas ke buku jurnal penerimaan kas, kemudian diarsipkan.

4. Bagian Bendahara Umum

Bertugas menerima surat pemberitahuan dari bagian mobilisasi dana tentang transfer dana dari Bank, dan menerima jurnal dan laporan keuangan untuk dicocokkan ke jurnal penerimaan kas dari bagian jurnal dan laporan.

5. Bagian Sekretariat

Bertugas menerima semua surat pemberitahuan dari bendahara umum tentang penerimaan kas perusahaan.

6. Bagian Kas

Menerima daftar surat pemberitahuan dan kwitansi dari bagian sekretariat, membuat bukti setoran ke bank sebanyak 3 lembar, menyetor cek dari langganan ke bank dan bukti setoran dan 1 lembar untuk arsip bagian kasa.

\section{Pembahasan \\ Evaluasi Penerapan Sistem Pengendalian Internal Secara Umum}

Evaluasi terhadap pengendalian internal secara umum, didapatkan fakta-fakta atas aktivitas di BLU RSUP Prof. Dr. R.D Kandou. Terdapat fakta yang merupakan kelebihan, dan ada fakta yang merupakan kelemahan. Fakta-fakta yang diperoleh adalah BLU RSUP Prof. Dr. R.D Kandou menekankan kejujuran, ketertiban waktu dalam bekerja, dan peraturan mengenai ketepatan waktu dalam menyelesaikan tugas. Hal tersebut dilakukan agar tingkat kedisiplinan dari semua pegawai baik dari ketepatan absensi dari masing-masing pegawai. Aktivitas pengendalian dari hal pemisahan tugas dan sistem otorisasi sudah dilakukan dengan baik. Sedangkan terhadap pengelolaan dokumen secara umum harus lebih tertata dengan baik agar mudah dimengerti dan mempermudah pendataan. Pengendalian secara fisik telah memadai dilihat dari perusahaan mendata setiap tamu atau pelanggan yang datang, kunci perusahaan hanya dipegang oleh security perusahaan sehingga tidak ada personel lain yang memiliki kunci ruangan kemudian perusahaan memiliki ruangan khusus untuk menyimpan dokumen-dokumen penting dan akses ke dalam ruangan tersebut hanya dimiliki oleh personel yang berwenang. Manajemen BLU RSUP Prof. Dr. R.D Kandou memiliki cara atau standar komunikasi antarbagian dan sub-bagian, dengan surat pemberitahuan mengadakan rapat yang harus dihadiri oleh masing-masing unit. BLU RSUP Prof. Dr. R.D Kandou hanya memiliki peraturan umum perusahaan dan belum memiliki peraturan kode etik secara tertulis, sehingga BLU RSUP Prof. Dr. R.D Kandou belum bisa menekankan secara tegas pentingnya kompetensi terhadap pegawainya, karena sangatlah penting jika dilakukan pelatihan secara 
berkala dan juga dilakukan penilaian kinerja berdasarkan pokok-pokok tugas masing-masing pegawai. Susunan struktur organisasi secara umum sudah memadai dan juga memiliki auditor internal, jadi selama ini penilaian risiko dilakukan subbidang sehingga memiliki laporan hasil audit internal, akan tetapi sistem pencatatan dan pelaporan keuangan yang sudah menggunakan sistem komputer yang harusnya mendapat pengawasan ketat sehingga pekerjaan tidak dapat selesai secara efisien.

\section{Evaluasi Penerapan Sistem Pengendalian Internal Penerimaan Kas}

BLU RSUP Prof. Dr. R.D Kandou sebaiknya dilakukan pelatihan secara berkala dan juga dilakukan penilaian kinerja berdasarkan pokok-pokok tugas masing-masing pegawai, dan melakukan pengawasan secara ketat kepada setiap pegawainya terutama pada bagian pencatatan dan pelaporan keuangan khususnya penerimaan kas sehingga meminimalkan adanya kemungkinan kecurangan atau penyimpangan uang kas. Penerapan pengendalian internal dan sistem akuntansi terhadap penerimaan kas sudah baik walaupun ada masalah dalam hal softfile dari daftar peserta yang baru dimiliki pada akhir bulan sehingga dapat menyebabkan meningkatnya kemungkinan adanya transaksi yang lupa atau tidak tercatat oleh pihak bank. Oleh karena itu, harus dibuat kebijakan bahwa data softfile daftar peserta harus terbaharui setiap hari. Apabila terjadi pergerakan uang di kasir, harus ada approval dari Bagian Akuntansi dan Keuangan. Hal tersebut diharapkan agar tidak adanya penyalahgunaan kas kecil.

\section{Kesimpulan}

\section{PENUTUP}

Berdasarkan evaluasi yang telah dilakukan, pengendalian internal secara keseluruhan maupun yang berkaitan dengan penerimaan kas BLU RSUP Prof. Dr. R.D Kandou yang dibuat oleh manajemen sudah memadai dan dapat melindungi aset dan meminimalkan risiko yang dapat menghambat kinerja dan operasional perusahaan. Namun, selain hasil evaluasi yang telah disebutkan di atas, dapat disimpulkan bahwa masih terdapat beberapa masalah yang harus diperhatikan dan menjadi pertimbangan manajemen BLU RSUP Prof. Dr. R.D Kandou, yaitu kurangnya pedoman tertulis dan konkret atas kode etik, penyampaian informasi, pelatihan bagi para pegawai secara berkala dan harus ada pengawasan secara ketat.

\section{Saran}

Berdasarkan hasil evaluasi yang telah dijelaskan, rekomendasi dan saran yang mungkin dapat membantu manajemen dalam BLU RSUP Prof. Dr. R.D Kandou untuk meningkatkan efektivitas kinerja dan operasional perusahaan khususnya dalam pengendalian penerimaan kas. Rekomendasi-rekomendasi tersebut adalah: perusahaan membuat kebijakan baru yang secara jelas menyatakan berkas harus dikirim sehari setelah transaksi berlangsung dan sampai diperusahaan maksimal satu minggu lamanya; bagian pertanggungan melakukan pencocokan berkas dengan softfile setiap berkas sampai di perusahaan, tidak hanya di akhir bulan atau awal bulan selanjutnya; manajemen pada setiap bagian memiliki pedoman dan peraturan tertulis dalam bertukar informasi atau dokumen ke bagian lain atau subbagian masing-masing. Peraturan tersebut misalnya: peraturan permintaan dokumen atau data antarbagian, peraturan permintaan dokumen atau data antarsubbagian. Sedangkan terhadap pengelolaan dokumen secara umum harus lebih tertata dengan baik agar mudah dimengerti dan mempermudah pendataan. Apabila terjadi pergerakan uang di kasir, harus ada approval dari Bagian Akuntansi dan Keuangan. Hal tersebut diharapkan agar tidak adanya penyalahgunaan kas kecil. Selain itu perusahaan dapat mengetahui setiap pelaporan keuangan. Oleh karena itu perusahaan disarankan agar dapat mengadakan pemeriksaan secara mendadak (surprised audit) sehingga aset perusahaan dapat terawasi. 


\section{DAFTAR PUSTAKA}

Abdul Halim dan Bambang Supomo. 2001. Auditing: Dasar-Dasar Audit Laporan Keuangan. Edisi Kedua. Yogjakarta

Donald E. Keiso, Jerry J. Weygandt, Terry D. Warfield. 2008. Akuntansi Intermediate. Jilid 1. Erlangga, Jakarta.

Horison, Horngren. 2004. Akuntansi di Indonesia . Salemba Empat Patria.

Ikatan Akuntan Indonesia. (2010). Standar Akuntansi Keuangan. Penerbit : Salemba Empat. Jakarta

Krismiadji. 2005. Sistem Informasi Akuntansi. Edisi Kedua. Akademia Manajemen Perusahaan YKPN. Yogyakarta

Lili M. Sadeli. 2006. Dasar-Dasar Akuntansi. Jakarta

Mulyadi, 2004. Sistem Akuntansi, Edisi Pertama. Salemba Empat, Jakarta.

Mulyadi. 2008. Sistem Akuntansi, Edisi Ketiga, Cetakan Keempat, Salemba Empat, Jakarta.

Rudianto. 2009. Pengantar Akuntansi. Erlangga. Jakarta.

Warren S. Carl, James M. Reeve dan Philip E. Fees. 2005. Pengantar Akuntansi. Edisi 21. Salemba Empat, Jakarta. 